\title{
IMPLEMENTATION OF ADVANCED CONTROL METHODS FOR IMPROVED VEHICLE DYNAMICS AND SAFETY USING CO-SIMULATION APPROACH
}

\author{
Vasko Čangoski, Igor Đurkov, Vase Jordanoska \\ Institute of Mechanical Construction, Mechanization Machines and Vehicles, \\ Faculty of Mechanical Engineering, "Ss. Cyril and Methodius" University in Skopje, \\ P.O. Box 464, MK-1001 Skopje, Republic of North Macedonia \\ vasko.changoski@mf.edu.mk
}

\begin{abstract}
A b s t r a c t: The increasing application of mechatronic devices in everyday life increases the demands for higher reliability and safety in order to achieve more sustainable systems. Inspired by the enormous efforts put in decreasing the number of accidents on the roads which is attributed to implementation of improved mechatronic systems, a controller for improved vehicle dynamics was created and comparison between two advanced control methods was made. Improved vehicle dynamics and stability control system is mandatory for most vehicles, and in order to make contribution in this field, a cascade controller for selective wheel braking control is implemented in a virtual 3D vehicle model. By using sliding mode control (SMC) and Linear Quadratic Regulator (LQR) as adopted control methods, an improved vehicles dynamics is achieved and also a more reliable system is created due to the adaptiveness of the control strategies. Using co-simulation approach involving ADAMS/Car and Matlab/Simulink, results for standardized vehicle maneuvers are obtained and the benefits of the proposed controllers are analyzed.
\end{abstract}

Key words: co-simulation; vehicle stability control; sliding mode control; linear cuadratic regulator; selective wheel braking

\section{ИМПЛЕМЕНТАЦИЈА НА НАПРЕДНИ УПРАВУВАЧКИ МЕТОДИ ЗА ПОДОБРЕНА ДИНАМИКА НА ВОЗИЛАТА И БЕЗБЕДНОСТ СО КОРИСТЕЊЕ НА КОСИМУЛАИСКИ ПРИСТАП}

А п с т р а к т: Зголемената употреба на мехатронички системи во секојдневниот живот ја зголемува потребата за поголема надежност и безбедност со цел да се создадат поодржливи системи. Инспирирани од огромните напори вложени во намалување на бројот на сообраќајни несреќи, што претставува заслуга на имплементацијата на подобрени мехатронички системи, контролер за подобрена динамика на возилата беше креиран и направена е споредба помеѓу две напредни управувачки методи. Подобрена динамика на возилата и систем за контрола на стабилноста е задолжителен за повеќето возила, а со цел да се даде придонес во оваа истражувачка област, каскаден контролер за селективно кочење на тркалата е имплементиран во виртуелен 3D модел на возило. Со употреба на управување со помош на лизгачка површина (УЛП) и линеарен квадратен регулатор (ЛКР) како усвоени управувачки методи, постигната е подобрена динамика на возилата, а воедно поради адаптивноста на самите стратегии, креиран е понадежен систем. Со користење на косимулациска околина, вклучувајќи АДАМС/Автомобил и МАТЛАБ/Симулинк, добиени се резултати за стандардизирани тест методи и направена е анализа на придобивките од предложените контролери.

Клучни зборови: косимулација; контрола на стабилноста на возилото; управување со помош на лизгачка површина; линеарен квадратен регулатор; селективно кочење на тркалата

\section{NOMENCLATURE}

A State matrix

B Input matrix

E Disturbance matrix
$F_{y} \quad$ Lateral tire forces

$I_{z} \quad$ Material moment of inertia

$K_{\alpha f}$ Front wheel cornering stiffness

$K_{\alpha r}$ Rear wheel cornering stiffness 


\author{
$l \quad$ Wheelbase \\ $l_{f} \quad$ Distance from the center of mass to the \\ front axle \\ $l_{r} \quad$ Distance from the center of mass to the \\ rear axle \\ $m$ Mass of the vehicle \\ $M_{z}$ Yaw moment \\ $S \quad$ Sliding mode surface function \\ $V_{x} \quad$ Longitudinal velocity \\ $V_{y} \quad$ Lateral velocity \\ $\delta_{i} \quad$ Steering wheels angle \\ $\theta_{p}$ Front wheels steering angle \\ $\omega_{z}$ Vehicle yaw rate
}

\section{INTRODUCTION}

With the tendency to create safer vehicles with improved performances, it is impossible to imagine the vehicles without integrated mechatronic systems. So, a greater effort must be made in improving and creating more sustainable mechatronic systems with improved control algorithms. Due to the fact that in the near future more and more autonomous vehicles would be produced and the creation of intelligent transport systems would be intensified, the safety of the passenger and the surrounding will largely depend on the functionality and reliability of the mechatronic systems.

One of the most common mechatronic system for improving the stability of the vehicle by selective wheel braking, commercially known as Electronic Stability Program (ESP) is described by Anton Van Zanten in [11], [12] and [13]. This system is now mandatory in every vehicle sold in the EU.

Several control algorithms for the selective wheel braking are proposed such the fuzzy control [7], neural network method and other advanced control methods.

In [14] the use of optimal control method in automotive industry and in future automotive vehicles is proposed. A controller with sliding mode control as part of the advanced control method used for improved vehicle dynamics based on individual wheel braking is proposed in [15] where the research is made in co-simulation environment. Another application of sliding mode control is explained in [5] for traction controller for future electric vehicles driven by hub motors.

The optimal control based on yaw moment control is described in [2] where a detailed explanation of the controller design based on LQR (linear quadratic regulator) calculated by Hamiltonian function is given.

One of the most used models for analytical research is the bicycle model. This model is used in [2] and [5], as prime model for research, while this model can be used also as reference model in cosimulation analysis. Using a virtual vehicle model in ADAMS and a reference bicycle model created in Matlab/Simulink is analyzed in [8], [10] and [15].

Considering the increased presence of mechatronic systems in vehicles and the idea of creating more reliable and sustainable systems, a co-simulation analysis using virtual vehicle model in ADAMS/Car and a reference bicycle model in Matlab/Simulink was performed. A mechatronic system used for selective wheel braking is integrated in the virtual vehicle model. Also, a cascade controller is proposed for the control of the mechatronic system. Advanced control methods used for the improving the performance and stability of the vehicle are sliding mode control and linear quadratic regulator.

The performance of this virtual mechatronic system is analyzed in co-simulation environment for several standardized vehicle dynamics maneuvers.

\section{VEHICLE MODELS}

The co-simulation was conducted using a virtual vehicle model from the ADAMS/Car and a reference bicycle model created in Simulink. This method was used in order to unify the advantages of using a virtual 3D model in order to gain more realistic results and advantages of using the Matlab/ Simulink software for modelling a cascade controller based on advanced control methods. In this research paper, the analysis and the simulations were performed using parameters of a representative vehicle from the B - segment. Using the ADAMS/Car module, this vehicle was specially created for this research and its primary parameters are presented in the Table 1.

The virtual ADAMS/Car model has two MacPherson suspension systems, steering rack and pinion system and tires modelled using the Magic Tire Formula. Also, the chassis of the vehicle is not visually presented but its characteristics such as the mass and the moment of inertia are defined at the center of the mass of the vehicle. Figure 1 shows the virtual vehicle model. 
Ta ble 1

Virtual Vehicle Model Parameters in ADAMS/CAR

\begin{tabular}{lc}
\hline \hline Mass: & $1143.5 \mathrm{~kg}$ \\
Axle weight distribution (front/rear): & $55 / 45 \%$ \\
Length: & $4040 \mathrm{~mm}$ \\
Width: & $1734 \mathrm{~mm}$ \\
Height: & $1483 \mathrm{~mm}$ \\
Wheelbase: & $2493 \mathrm{~mm}$ \\
Front track width: & $1508 \mathrm{~mm}$ \\
Rear track width: & $1471 \mathrm{~mm}$ \\
\hline \hline
\end{tabular}

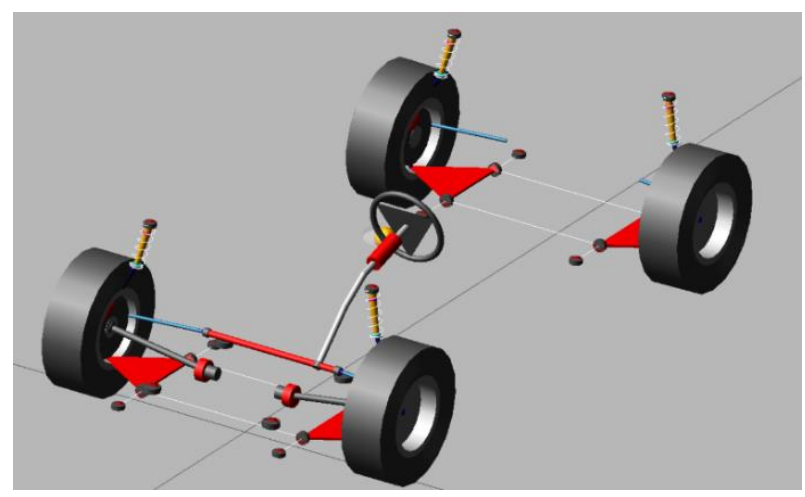

Fig. 1. Virtual vehicle model in ADAMS/Car

In order to assemble the co-simulation environment and to simulate the mechatronic system responsible for the improving the vehicle dynamics, a control system for selective wheel braking is implemented in Matlab/Simulink. This model is simulated by defining an input signals for the activation of the vehicle's brakes. The input signals to the ADAMS/CAR model are the applied braking torques of each wheel, making it a total of 4 input signals. The output signals are the lateral acceleration, vehicle yaw rate, vehicle side-slip angle and the steering angle value. They are used as inputs for the controller in Matlab/Simulnik.

As reference model for the controllers, a bicycle model with two degrees of freedom (Figure 2), presented in [2] is used.

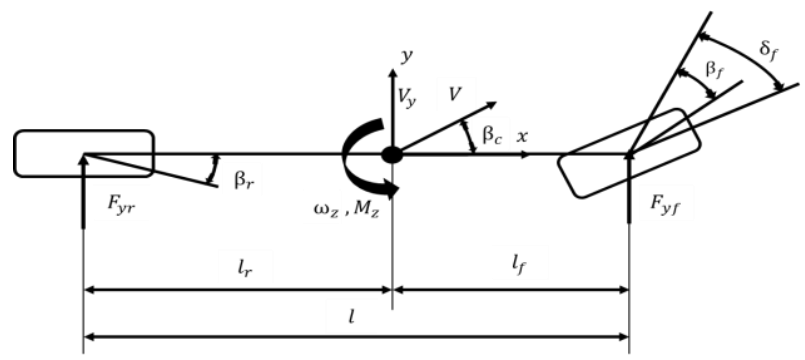

Fig. 2. Bicycle model
The equations that define the model are presented in (1) and (2). While the state-space format of the system are shown in (3). The used parameters of the bicycle model are presented in Table 2.

$\dot{V}_{y}=\left(\frac{-K_{\alpha f}-K_{\alpha r}}{m V_{x}}\right) V_{y}+\left(\frac{K_{\alpha r} l_{r}-K_{\alpha f} l_{f}}{m V_{x}}-V_{x}\right) \omega_{z}+\frac{K_{\alpha f}}{m} \delta_{f}$

$$
\dot{\omega}_{z}=\left(\frac{K_{\alpha r} l_{r}-K_{\alpha f} l_{f}}{I_{z} V_{x}}\right) V_{y}+\left(\frac{-K_{\alpha f} l_{f}{ }^{2}-K_{\alpha r} l_{r}{ }^{2}}{I_{z} V_{x}}\right) \omega_{z}+\frac{K_{\alpha f} l_{f}}{I_{z}} \delta_{f}
$$

$A=\left[\begin{array}{cc}\frac{-K_{\alpha f}-K_{\alpha r}}{m V_{x}} & \frac{K_{\alpha r} l_{r}-K_{\alpha f} l_{f}}{m V_{x}}-V_{x} \\ \frac{K_{\alpha r} l_{r}-K_{\alpha f} l_{f}}{I_{z} V_{x}} & \frac{-K_{\alpha f} l_{f}^{2}-K_{\alpha r} l_{r}^{2}}{I_{z} V_{x}}\end{array}\right], B=\left[\begin{array}{c}\frac{K_{\alpha f}}{m} \\ \frac{K_{\alpha f} l_{f}}{I_{z}}\end{array}\right]$

T a b l e 2

\section{Bicycle Vehicle Model Parameters}

Mass [m]:

$1143.5 \mathrm{~kg}$

Wheelbase $[l]$

$2493 \mathrm{~mm}$

Distance from center of mass to front axle $\left[l_{f}\right]$ :

$1122 \mathrm{~mm}$

Inertia radius $[i]$

$1250 \mathrm{~mm}$

Front wheel cornering stiffness $K_{\alpha f}$ ):

$77000 \mathrm{~N} / \mathrm{rad}$

Rear wheel cornering stiffness $\left(K_{a r}\right)$

$77000 \mathrm{~N} / \mathrm{rad}$

\section{CASCADE CONTROLLER DESIGN WITH INTEGRATED ADVANCED CONTROL METHODS}

Considering the importance of the vehicle's stability and safety it can be stated that the components integrated in the selective wheel braking system must act fast and in a decisively manner. In this paper the control of the selective wheel braking system is made by using the linear quadratic regulator and sliding mode control.

The decision for researching improved vehicle dynamics by using these advanced control methods was made because of the higher adaptiveness of the system that they offer in comparison of using conventional control methods. The purpose of these research was to compare the optimal output offered by the LQR and the increased robustness of the controller allowed with the usage of the SMC.

Using the input of the vehicle yaw rate and the direction of turning of the steering wheels, the controller finds out whether the vehicle demonstrates understeering or oversteering characteristics. The 
decision making process for braking intervention is presented in Table 3 where $\omega_{z}$ represents the vehicle yaw rate of the ADAMS model and $\omega_{\text {ref }}$ is the desired yaw rate obtained from the reference bicycle model in Matlab/Simulink.

Table 3

Breaking wheel control decision [7]

\begin{tabular}{|c|c|c|c|c|}
\hline$\omega_{\text {ref }}$ & $\omega_{z}$ & $-\omega_{r e f}$ & Steering & Braked wheels \\
\hline \multirow{2}{*}{$\omega_{\text {ref }}>0$} & & $\geq 0$ & Oversteer & Right wheels \\
\hline & & $<0$ & Understeer & Left wheels \\
\hline \multirow{2}{*}{$\omega_{\text {ref }}<0$} & & $>0$ & Understeer & Right wheels \\
\hline & & $\leq 0$ & Oversteer & Left wheels \\
\hline
\end{tabular}

It must be pointed out that in the bicycle model and in the virtual ADAMS/Car model, turning to the left is considered as a positive direction with a positive value for the yaw rate.

On the other hand, the controller where the advanced control method is implemented calculates the necessary braking torque needed to stabilize the vehicle.

Using LQR as a control algorithm a Hamiltonian function [2] is used, where the yaw moment generated by the braking of the wheels is used as an input, while the steering wheel angle is used as an external disturbance. The equation that defines the bicycle model now obtains the following form:

$$
\dot{x}=\mathrm{A} x+\mathrm{B}_{1} M_{z}+\mathrm{E} \theta_{p}
$$

The matrix $\mathrm{A}$ is identical to the one given above, while the matrices $\mathrm{B}_{1}$ and $\mathrm{E}$ now are defined as:

$$
\mathrm{B}_{1}=\left[\begin{array}{l}
0 \\
\frac{1}{I}
\end{array}\right] \quad \mathrm{E}=\left[\begin{array}{c}
\frac{K_{\alpha f}}{m} \\
\frac{K_{\alpha f} l_{f}}{I_{z}}
\end{array}\right]
$$

where the matrix E represents the disturbance matrix. The output corrective yaw moment is calculated using (6).

$$
M_{z}=K_{\omega} \omega_{z}+K_{v_{y}} v_{y}+K_{\delta} \delta
$$

Values of the matrixes used in the input function, $K_{\omega}, K_{v_{y}}$ and $K_{\delta}$ are generated "online" while the system is evaluating the appropriate corrective yaw moment. These values are calculated using the cost function with the matrices described in (7).

$$
\begin{aligned}
& \mathrm{J}=\frac{1}{2} \int_{0}^{\infty}\left[\left(X_{d}-X\right)^{T} Q\left(X_{d}-X\right)+U^{T} R U\right] d t \\
& U=\left[M_{z}\right], R=[w], \quad Q=\left(\begin{array}{ll}
0 & 0 \\
0 & 1
\end{array}\right) \text { и } X_{d}=\left(\begin{array}{c}
0 \\
f_{u} \delta
\end{array}\right)
\end{aligned}
$$

where $f_{u}$ is a function that defines the vehicle speed and $w$ is a weighting factor. The entire procedure of calculating the desired output is described in [2], while the weighting factor $w$ for this vehicle has the value of $w=3 \cdot 10^{-8}$. This value of 3 , was defined after few simulations and it be can stated that, by increasing the value of the coefficient, the system and the entire vehicle becomes faster in their response, but it generates higher amplitudes in the output results, while the exponent determines the rang of the value of the output signal.

In the other case, we use sliding mode control for the previously mentioned controller. In theory by using this type of control, the system should "slide" along a surface that defines the best and desired response from it. By moving away from the surface, the controller must act in order to return the system in the desired position. Because of this it is necessary to define the sliding surface and in our case it was determined that the sliding surface should be defined as $s=0$, which means that in the stationary condition, the actuators would not be active. On the other hand, the functions that will activate the actuators are defined in (9).

$s=\dot{e}+\lambda e(9)$

Where the error (e) is defined as $e=0$ in stationary condition. The value of the coefficient $\lambda$ is adopted to be $\lambda=30$, which allows some improvements in the entire system. Several attempts were made using different values of the coefficient $\lambda$, but it was concluded that this value is most suitable for our vehicle.

Unlike the corrective yaw moment which is the output of the controller using the LQR, in this case the output of the system is defined to be the value of the hydraulic pressure of the braking system. The output variable of the hydraulic pressure of the sliding mode controller is defined as:

$$
u=k \tanh \left(\frac{s}{\phi}\right)+u_{e q}
$$

where $k=6$, while $\phi=10$ and $u_{e q}=0$

The value of the coefficient $k$ defines the maximal pressure of the hydraulic system of the front brakes expressed in $\mathrm{MPa}$, while the value of $4 \mathrm{MPa}$ for the maximal pressure of the rear brake is derived by simple proportion. $u_{e q}$ represents the desired 
pressure of the system when there is no need for intervention in the system and the $\phi$ defines the thickness of the boundary layer of the sliding mode surface. This value best suitable for this simulation is $\phi=10$. Lower values lead to a more aggressive system, frequent activation of the actuators and worse vehicle performance, while the higher values decreased the chattering of the system, but it resulted in smaller amplitudes and slower response from the controller which led to reduced efficiency of the control method. To summarize all the previous conclusions, the final form of the output signal from the controller is presented in (11).

$$
u=6 \tanh \left(\frac{\dot{e}+30 e}{10}\right)
$$

The final stage of the controller must also be explained. Due to the fact that both of the control strategies are based on the difference between the actual and the desired value of the yaw rate of the vehicle, they are activated even when there is a neglectable difference between the two values. This will result in much improved safety of the vehicle and would make the entire mechatronic system and the vehicle itself a highly effective system. But on the other hand, the performance of the vehicle would be drastically worsen due to the frequent activation of the actuators. In order to optimize the vehicle performance and to increase its safety, the final controller of the entire cascade controller is added, which determines whether to execute the commands from the previous controllers or not.

This is solved using the phase-plane method $(\beta+\dot{\beta})$ which uses the values of the side slip angle of the vehicle and its derivative. Control method of this system is derived from

$$
\left|\mathrm{C}_{1} \beta+\mathrm{C}_{2} \dot{\beta}\right| \leq 1
$$

where the $C_{1}$ and $C_{2}$ are determined by experiment and several simulations. A recommendation in [7] for the values of $C_{1}$ and $C_{2}$ is $C_{1}=2.41$ and $C_{2}=$ 9.615 and those values were proven to be suitable for this vehicle too. By decreasing the values of the coefficients, we would increase the stable region of the controller which could result in preventing the selective wheel braking system from activating entirely. On the other hand if we increase the coefficient we would make the activation of the selective wheel braking system more frequent and that would result in more stable vehicle, but with degrade performance.

Using all of the previously mentioned controllers, a cascade controller for the selective wheel braking system was created which send input data to the actuators of the braking system whether to be activated or not. Using this controller, the results from the co-simulation are presented in the next section.

\section{SIMULATION RESULTS}

In order to evaluate the proposed system, cosimulation using Matlab/Simulink and ADAMS Car was conducted. The modeling of the controllers was done in the Simulink, while the virtual vehicle represents the tested vehicle model. The output data of the ADAMS model are lateral acceleration, yaw rate, side-slip angle and steering wheel angle. These variables are used as input data in the Simulink model, while the output variables of the Simulink model which represents the input data for the ADAMS model at the same time, are the braking pressure for the sliding mode control and the braking torque of the wheels for the linear quadratic regulator.

The test maneuvers that were used to compare the vehicle behavior are step steer turning and single lane change. In the next analysis a comparison between the vehicle without selective wheel braking system, vehicle with selective wheel braking controller using sliding mode control (SMC Vehicle) and vehicle with selective wheel braking controller using Linear Quadratic Controller (LQR Vehicle) is presented.

In the step steer turn maneuver the vehicle is traveling with a speed of $80 \mathrm{~km} / \mathrm{h}$ and the maximal steering wheel angle is $110^{\circ}$ (Figure 3 ). This angle was determined in order to reach the vehicle limits for the given road condition defined with its friction coefficient $\varphi=0.9$.

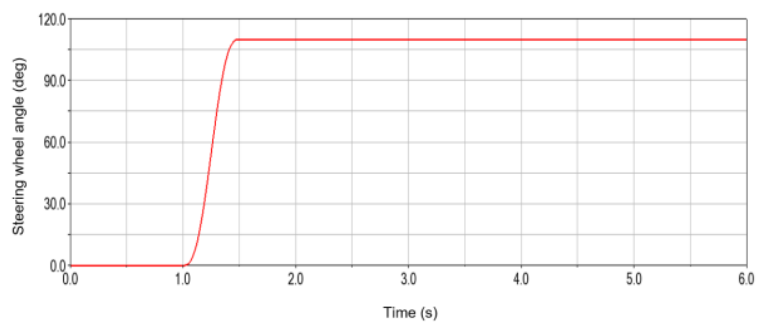

Fig. 3. Steering wheel angle - step steer maneuver

Reviewing the results for the lateral acceleration we can state that these limits are reached, especially by the vehicle without selective wheel braking system. As well as for the lateral acceleration, 
the similar conclusions can be drawn by examining the diagram of the yaw rate. It can be concluded that the vehicles which have the selective wheel braking system, have smaller amplitudes, and faster response time. The oscillation that can be noticed in the transient state (Figures 4 and 5) are result of the impulsive activation of actuators that activate the brakes, but do not cause instability of the vehicle response. In a real situation, due to the inertia of the mechanical system of the vehicle and the actuators, these oscillations would be reduced.

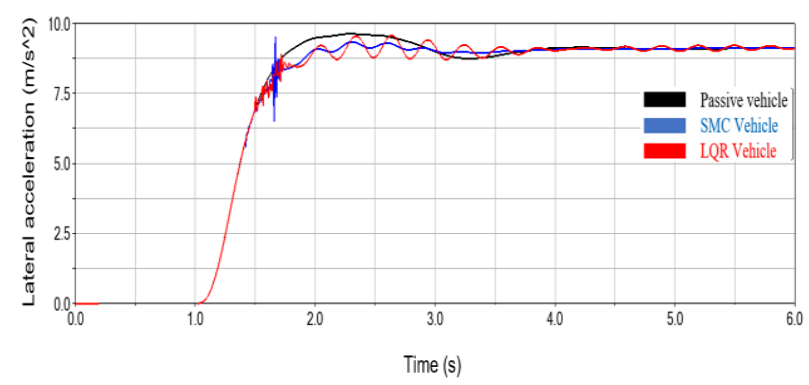

Fig. 4. Lateral acceleration - step steer maneuver

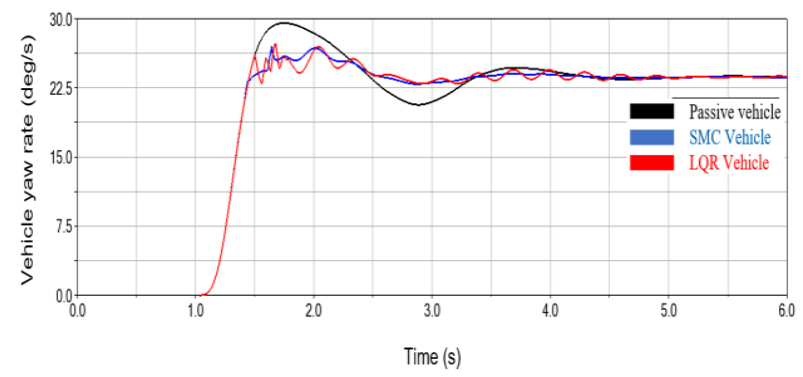

Fig. 5. Vehicle yaw rate - step steer maneuver

The improvement by using selective wheel braking system and the mechatronics systems in general can be also observed in Figure 6 with the vehicle side-slip angle where it is obvious that the vehicles with integrated selective wheel braking system have smaller values, which would result in improved vehicle handling. It is interesting to point out the difference in the output commands and the control logic of the two advanced control methods. In Figure 7 the braking torque of the right front wheels is presented. It can be concluded that the sliding mode controller acts more impulsively and more frequently, but also with higher amplitudes. On the other hand, the activation of linear quadratic regulator occurs less frequently, but with bigger threshold of the activation command. Beside of the aggressive response form the actuators, no instability is caused in the vehicle's response.
After conducting this analysis, it can be concluded that both control methods are improving the dynamics and safety of the vehicle, but it can not be explicitly stated which control method is better. Because of this, further analysis and simulations were performed.

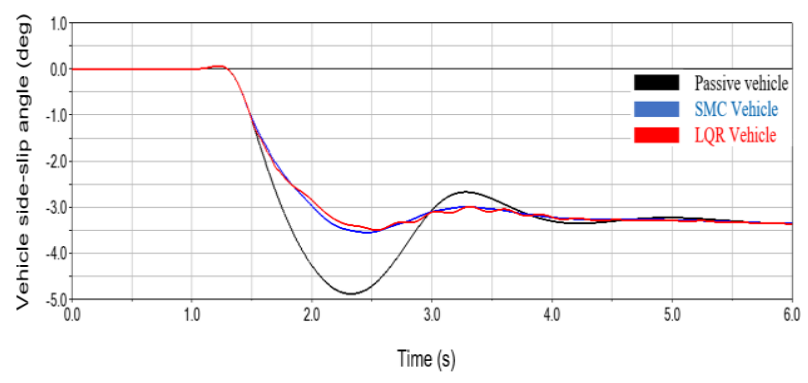

Fig. 6. Vehicle side-slip angle - step steer maneuver

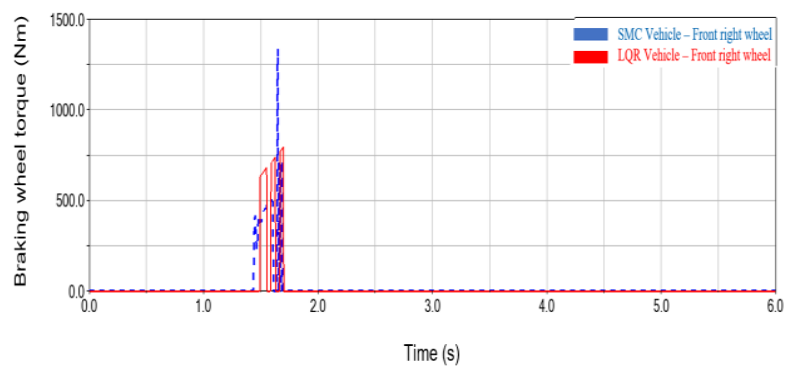

Fig. 7. Front right braking wheel torque - step steer maneuver

Next, the co-simulation of the single lane change maneuver was conducted. The vehicle is traveling with speed of $100 \mathrm{~km} / \mathrm{h}$ and the value of maximal Analyzing the the yaw rate it can be confirmed that both vehicles with $\mathrm{s} 95^{\circ}$ (Figure 8 ). The speed of the vehicle was increased from the previous analysis, due to the fact that in a co-simulation conducted with speed of $80 \mathrm{~km} / \mathrm{h}$ the same conclusions were made like in the previous step-steer analysis. Because of this, the velocity was increased in order to push the vehicle to the limits.

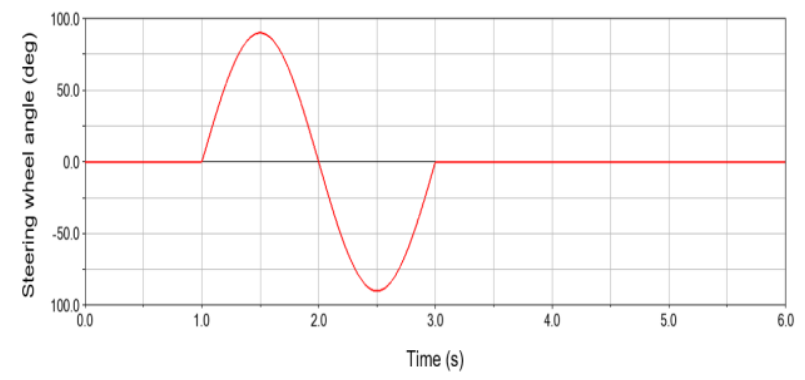

Fig. 8. Steering wheel angle - single lane change

Analyzing the results for the lateral acceleration Figure 9) and the yaw rate (Figure 10) it can be 
confirmed that both vehicles with selective wheel braking system have faster response, especially in the first part of the manoeuvre. Also, the amplitudes of the observed variables are lower. But there is a huge difference in the second part of the manoeuvre when the vehicle is trying to change the driving lane and complete the manoeuvre successfully. Despite the quick response, it is obvious that the amplitudes and the time needed for the vehicle LQR to complete the manoeuvre are the same as the vehicle without selective wheel braking system. Also, during the entire co-simulation the SMC vehicle generates almost half the value for the side-slip angle (Figure 11), unlike the LQR vehicle which obviously fails in the second part of the manoeuvre.

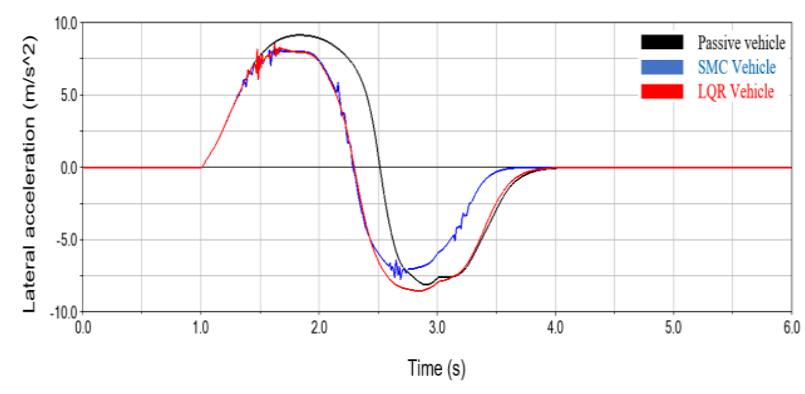

Fig. 9. Lateral acceleration - single lane change

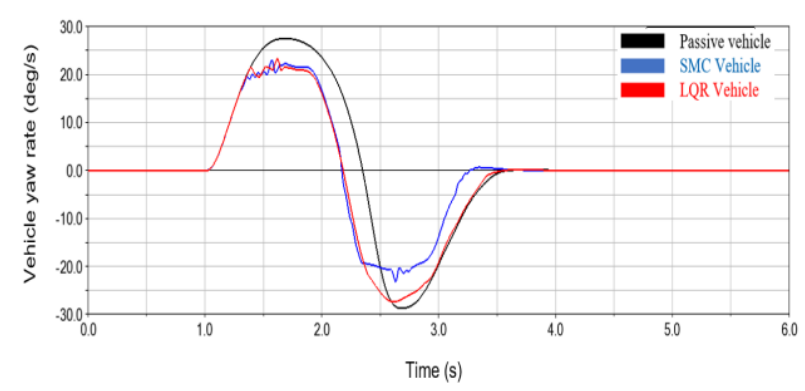

Fig. 10. Vehicle yaw rate - single lane change

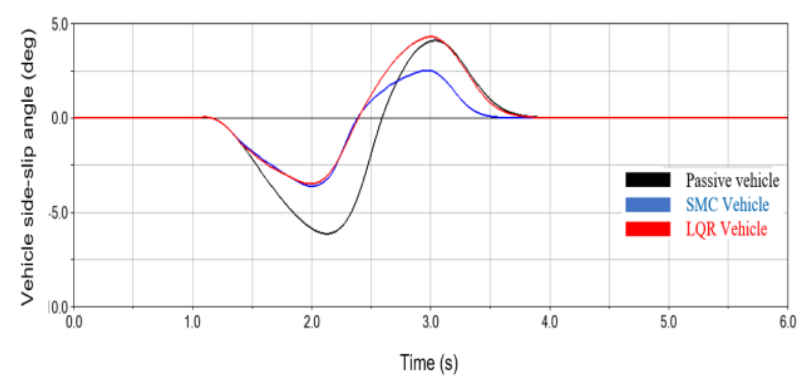

Fig. 11. Vehicle side - slip angle - single lane change

The explanation for this behavior is presented on Figure 12. Analyzing the activation of the actuators, it can be concluded that the selective wheel braking system that uses the sliding model control activates the system during the left and the right turn. On the other hand, the Linear Quadratic Regulator is activated only during the first turn. The lack of activation of the controller and the actuators of the system with implemented LQR results in less reliable system. Moreover, the maximal braking torque of the SMC vehicle is almost twice higher than the braking torque of the LQR vehicle. Higher braking torque, more impulsive activation of the controller and activation of the system during the entire maneuver result in better results using the sliding mode controller for the ESP. This makes the vehicle more reliable and safer.

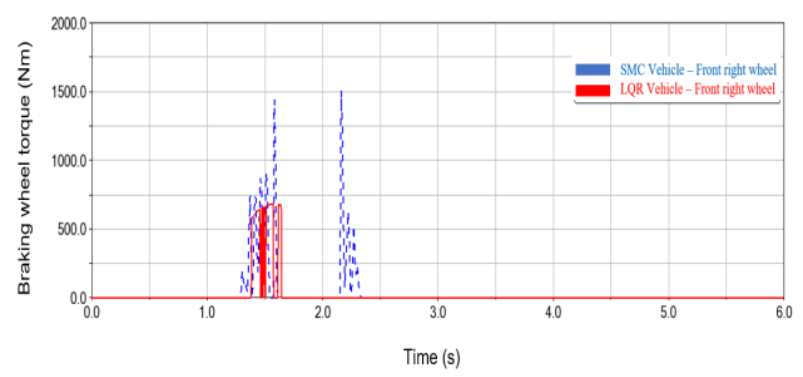

Fig. 12. Front right braking wheel torque - single lane change

\section{CONCLUSIONS}

The use of the co-simulation method involving ADAMS/Car and Matlab, allows to exploit the advantages of both software programs. The virtual model in ADAMS/Car with over 100 degrees of freedom is offering the opportunity to make a research of the vehicle dynamics which would generate results almost as similar as the results from a real vehicle testing. Also, the possibility to create a control method for any mechatronic system in Matlab/Simulink and its integration with $\mathrm{AD}$ AMS/Car offers the possibility to examine how the vehicle dynamics and its stability would improve using an integrated mechatronic system in the vehicle itself.

The research had shown that by using the advanced control methods, an improved performance and stability of the vehicle is achieved. By using the sliding mode control for the cascade controller, it can be stated that the vehicle has faster response and shorter settling time, while the amplitudes for the lateral acceleration, the yaw rate and the vehicle side-slip angle are smaller. This makes the vehicle safer and with better handling characteristics. The controller acts very impulsively and with high amplitudes which improves the overall situation of the 
vehicle. On the other hand, the linear quadratic controller improves the performance of the vehicle in the step-steer manoeuvre, but fails in the single lane change manoeuvre. This is a result of the less impulsive activation of the controller, smaller number of activations and smaller amplitudes of the desired braking torque of the wheels. From this analysis it can be concluded that the linear quadratic regulator generally improves the performance of the vehicle, but also fails in some more aggressive manoeuvres. Because of this the LQR should be created in a manner that the coefficients of the control algorithm should have their values assigned based on the input signals from the vehicle sensors, such as vehicle yaw rate, vehicle side-slip angle, etc. This adaptiveness would also be an improvement in using the sliding mode control, but it can be stated that this method is more robust to different driving situations and already possesses more adaptive capabilities to the newly created situations rather than the linear quadratic regulator.

As a final conclusion, it can be pointed out that the proposed cascade controller improves the overall dynamics, stability and handling of the vehicle and thus contribute to a safer "driver-vehicle" system as a unit part of a network of Intelligent Transport Systems. The implementation of the advanced control methods increases the overall adaptiveness of the system and contributes to more robust controllers. This robustness is more evident using the SMC controller in the single lane change manoeuvre because of the failed reaction of the $\mathrm{LQR}$ in the second part of simulation.

These conclusion in the research papers leads to the fact that beside the advantages of these controller over the conventional ones, they also possess certain limitations. By defining the controller algorithms using constant coefficients limits the adaptiveness of the system to different inputs and manoeuvres that are not tested. A next step for further research would be the implementation of an adaptive advanced control methods by implementing interpolation method or another algorithm for determining the values of the used coefficients. Their replacement with different and more suitable values for every different manoeuvre would lead to creation of a state of art controller.

\section{REFERENCES}

[1] Abe, M.: Vehicle Handling Dynamics, Second Edition, Elsevier, Oxford, 2015.

[2] Esmailzadeh, E., Goodarzi, A., Vossoughi, G. R.: Optimal yaw moment control law for improved vehicle handling, Mechatronics, vol. 13, Issue 7, Elsevier Science Ltd., 2003.

[3] Ferrara, A.: Sliding Mode Control of Vehicle Dynamics, The Institution of Engineering and Technology, London, 2017

[4] He, J., Crolla, D., Levesley, M., Manning, W.: Integrated Active Steering and Variable Torque Distribution Control for Improving Vehicle Handling and Stability, SAE Special Publication Vehicle Dynamics and Simulation 2004, Society of Automotive Engineers, Warrendale, $\mathrm{Pa}$, 2004.

[5] Jalili-Kharaajoo, M., Besharati, F.: Sliding mode traction control of an electric vehicle with four separate wheel drives, Proceedings of the 2003 IEEE Conference on Emerging Technologies and Factory Automation, Lisbon, 2003, vol. 2, pp. 291-296,

[6] Yorozu, Y., Hirano, M., Oka, K., Tagawa, Y.: Electron spectroscopy studies on magneto-optical media and plastic substrate interface, IEEE Transl. J. Magn. Japan, vol. 2, pp. 740-741, August 1987 [Digests 9th Annual Conf. Magnetics Japan, p. 301, 1982].

[7] Jin, L., Xie, X., Shen, C., Wang, F., Wang, F., Ji, S., Guan, $\mathrm{X}$., Xu, J.: Study on electronic stablity program control strategy based on the fuzzy logical and genetic optimization method, Advances in Mechanical Engneering, Vol. 9 (5), pp. 1-13, SAGE Journals, 2017.

[8] Li, S., He, L.:Co-simulation Study of Vehicle ESP System Based on ADAMS and MATLAB, Journal of Software vol. 6, SAGE Academy Publisher, 2011.

[9] Reif, K.: Brakes, Brake Contorl and Driver Assistance Systems, Function, Regulation and Components, Bosch Professional Automotive, Springer, Wiesbalden, 2014.

[10] Saha, S., Amrr, S., M.: Design of slip-based traction control system for EV and validation using co-simulation between Adams and Matlab/Simulink, Simulation: Transactions of the Society for Modeling and Simulation International, vol. 96, SAGE Journals, 2020.

[11] Van Zanten, A. T.: Bosch ESP Systems: 5 Years of Experience, Proceedings of the 2000 SAE Automotive Dynamics and Stability Conference, Society of Automotive Engineers, Warrendale, Pa, 2000.

[12] Van Zanten, A. T., Erhardt, R., Landesfeind, K., Pfaff, G.: VDC Systems Development and Perspective,", SAE Paper 980235, SAE Publication: Electronic Braking, Traction and Stability Control, SAE, Warrendale, $\mathrm{Pa}, 1999$.

[13] Van Zanten, A. T., Erhardt, R., Pfaff, G.: VDC, The Vehicle Dynamics Control System of Bosch, SAE Paper 950759, SAE Publication: Electronic Braking, Traction and Stability Control, SAE, Warrendale, Pa, 1995.

[14] Waschl, H., Kolmanovsky, I., Steinbuch, M.: Optimization and Optimal Control in Automotive Systems, Springer, London, 2014.

[15] Zhang, S., Zhou, S., Sun, J.: Vehicle Dynamics Control Based on Sliding Mode Control Technology, 2009 Chinese Control and Decision Conference (CCDC 2009), pp. 2435-2439, Guilin, 2009. 